\title{
APPLICATION OF A MATHEMATICAL MODEL FOR CONTAINER TRANSPORT FLOW OF GOODS: FROM THE FAR EAST TO SERBIA
}

\author{
Radoslav Rajkovic, Nenad Zrnic, Djordje Stakic
}

Original scientific paper Container transport represents a key component of intermodal transport and a substantial contribution to the rapidly growing international trade. The container trade should be optimal to provide a suitable resource utilisation and profitability to key operators, providing them an easy and relatively cheap access to international markets. Numerous algorithms have been generated to provide an efficient solution to optimisation problems in container trade. This paper analyses the supply-chain network focusing on container import from the Far East to Serbia through selected Mediterranean ports (Koper, Rijeka, Bar, Thessaloniki and Constanta). An optimisation mathematical model was developed, minimising the transit time and transportation costs of container imports to Serbia, by means of using various liner shipping services on the deep-short sea and truck-rail-barge inland transport networks from selected ports. By using the bi-objective model for container flows from the Far East through Mediterranean ports, the optimal path for container import to Serbia has been determined. Certain groups of customers require the lowest freight rates, while others give priority to a faster delivery.

Keywords: bi-objective optimisation; container transport; mathematical model

Primjena matematičkog modela za kontejnerske tokove robe: s Dalekog istoka ka Srbiji

Izvorni znanstveni članak

Prijevoz kontejnera predstavlja ključnu komponentu intermodalnog prijevoza i značajan je doprinos brzo rastuće međunarodne trgovine. Kontejnerski tok treba biti optimalan kako bi se osiguralo pravilno korištenje resursa i profitabilnost ključnim subjektima, pružajući im jednostavan i relativno jeftin pristup međunarodnim tržištima. Brojni algoritmi su razvijeni kako bi učinkovito izvršili rješavanje problema optimizacije kontejnerskih tokova. U radu se analizira intermodalna mreža s primarnim fokusom na uvoz kontejnera s Dalekog istoka ka Srbiji preko odabranih mediteranskih luka (Koper, Rijeka, Bar, Solun i Konstanca). Razvijen je optimizacijski matematički model, koji smanjuje vrijeme i troškove kontejnerskih uvoza u Srbiju, pomoću različitih servisa na moru i kamionskih, željezničkih i riječnih kopnenih tokova. Koristeći dvo-objektivni model za kontejnerske tokove s Dalekog istoka preko mediteranskih luka utvrđena je optimalna ruta za kontejnerski uvoz u Srbiju. Neki klijenti zahtijevaju niže cijene prijevoza, dok drugi trebaju brže isporuke.

Ključne riječi: dvo-objektivna optimizacija; kontejnerski transport; matematički model

\section{Introduction}

In 2015, global containerized trade was estimated to have increased by $5,3 \%$ and reached 180 million TEUs. For several decades, the containerised trade has been the fastest-growing market segment operating through a highly integrated, efficient network of trunk routes and feeder services. The sustained growth of container trade has been accompanied by the globalization of container shipping market. However, this sector of trade still remains vulnerable to potential risks that the world economy is facing [1].

Overall growth was boosted by the recovery of the head-haul journeys of the major East-West trans-Pacific and Asia-Europe trade lanes. As a result of the economic recovery in the United States and the similar developments in Europe, containerized trade volumes carried on the Asia-Europe and trans-Pacific peak legs are estimated to have increased by $7,5 \%$ and $6,3 \%$ respectively. On the other hand, trade volumes on backhaul journeys remained weak, reflecting the lower import demand in Asia. The weaker demand for imports from Europe and North America does not necessarily reflect a drop in the overall import demand, as imports from Asia often include waste and other residual products. Volumes on the westbound leg of the transPacific route declined, while shipments on the eastbound leg of the Asia-Europe trade route increased only marginally [1].

This paper addresses the issues related to the supplychain network, focusing on import of containers from the
Far East (Port of Shanghai) to Serbia (the city of Belgrade) through selected Mediterranean ports (Koper, Rijeka, Bar, Thessaloniki and Constanta), by examining operations of the six world's largest container carriers (Maersk Line - MSK, Mediterranean Shipping Company MSC, CMA CGM, Evergreen Line - EMC, China Ocean Shipping Company - COSCO and Hapag-Lloyd). Serbia is a hinterland country and the container import from the Far East to Serbia entails the use of combined deep sea and short sea shipping with different forms of inland transportation modes: truck, rail and barge. Given the negligibly small exported quantities, this paper examines solely the import of containers to Serbia.

In this study, a bi-objective optimisation model (BOOM) was developed, which minimises the transit time and transportation cost of container import from the Far East to Serbia. BOOM was programmed in MATLAB and simulations were carried out on a Dual Core E5200 $2.5 \mathrm{GHz}$ computer. Through minimisation of the time and cost for container import flow from the Far East through the Mediterranean nodes, the most optimal route was determined. This is particularly important in the light of the fact that the container import to Serbia reached 50000 TEU in 2014.

The BOOM's first objective is the minimisation of transport costs, while its other aim is the transit time minimisation. This reflects the needs of a diversified market, as certain groups of customers prefer the lowest freight rates, while others give priority to a faster delivery. 
The remaining section of the paper is organised as follows: Section 2 presents a brief review; Section 3 describes the problem addressed in this paper; Section 4 elucidates the mathematical model; Section 5 reports and analyses the results of the developed mathematical model. Finally, Section 6 presents conclusions and future developments.

\section{Literature review}

Containers assignment on intermodal networks still remains an open issue, despite the literature on freight transportation being rather extensive. By studying the literature data, the conclusion was made that the sea and land legs were investigated in a concurrent manner only by a small number of researchers $[2 \div 6]$. In most papers, an optimisation model developed was based on minimisation of only one objective - either transport cost or transit time.

Attaining minimisation of operating costs, including a fixed charge for each train, variable transport and handling costs for each container, as well as yard storage costs, while meeting on-time delivery requirements, was the principal objective of the authors of the paper [7]. The problem was formulated as an integer programme and a novel decomposition procedure was developed to find the most-optimal decisions.

An analysis of the freight costs of containers from several Chinese harbours to representative central European destinations was presented in the paper [8]. The paper results demonstrated that Italian ports, primarily those of Genoa and Trieste, are the most favourable terminals from the aspect of sea and overland transport cost-efficiency, when using both truck and rail, for a geographic range that does not include all the northern countries of the European Union and Russia; however, the above-range does cover a significant number of the southernmost cities of these countries such as Milan, Munich, Vienna, Budapest, Bern, Lyon, and Kiev.

A multimodal transportation issue discussed in [5], was the issue of designating the transportation trade, i.e. the volume of container goods, and the transportation way in every trade direction, with a view to minimising the sum of ocean and inland transport costs. Maximum cargo volumes capacitated at each seaport and the maximum number of vehicles available at each transportation mode was the two key restrictions that the problem had to consider. A mixed integer programming, which is an operation research technique, has been applied for the purpose of providing an optimal solution to the problem. A case study was conducted on the container cargo data in Korea, where several conclusions were drawn and later used to improve the efficiency in transportation of international trade cargoes in Korea.

In the following year, the authors conducted a similar study [4]. The focus of their research was on an intermodal shipping transport service in which containers represented the moved loading units. More precisely, the advantages of combining sea and road transport - the sea transport for carrying huge amounts over long distances, and the road transport for collecting and distributing over short or medium distances, were addressed in this work. A ship-truck intermodal transportation problem was formulated as a Travelling Purchaser Problem (TPP), expanding, in that manner, the TPP real-world application field, with the aim of minimising the total costs of service.

In order to identify the extent of use of short sea shipping and inland transportation, the authors [9], addressed the problem of defining the transportation quantity and mode in transporting international cargoes between Myanmar and its trading partners, particularly focusing on the countries in the South East Asia. The aim of the paper was to minimise transportation charges between the origin of goods and their destination, contingent upon maximum cargo volumes being handled at each seaport. The paper proposes a linear programming model with a view to optimising the short sea shipping and inland transportation in Myanmar

For the purpose of predicting the allocation to ports and transportation channels of containerised goods imported from Asia to the USA, the authors [6], in the framework of their research, proposed an analytical model. The Long-Run Model, is a large mixed integer non-linear programming model, with a set of heuristics used for problem-solving. Attaining minimisation of the total charges of transportation, handling, pipeline inventory, and safety-stock inventories is the primary objective of this model. The Long-Run Model generated Short-Run Model as one of its components and integrated it with a set of analytical queuing models.

A model for the transit assignment problem with a fixed set of transit lines was described in this paper [10]. Proposing a model and developing a solution algorithm for the problem of defining the network solution for transit participants, aimed at simulating the process over transit networks, was the principal objective of the paper. The issue was determined as a linear programming issue of a size that increases linearly with the network dimension. The authors developed a label-setting algorithm that solves the latter problem in polynomial time. The paper also addresses nonlinear cost extensions of the model.

Identifying the best path between each origindestination pair is not a trivial issue, and not the one that may be solved by hand, given the large number of maritime services characterised by different frequencies, travel times and capacity. Furthermore, the optimal trade assignment for overall transit time minimisation on the network does not necessarily correspond to finding the shortest route from each starting point to each final point, a problem that has been extensively addressed in the literature $[11 \div 13]$.

Analysing the previous investigations state that is based on selection of algorithms, in the 1980s general equilibrium principles were applied to shipping networks, explaining simultaneously the manufacturing, distribution, split mode and the task of freight flows [14], [15]. By means of introducing commodity differentiation, probabilistic choice models and inventory considerations, those models were extended in this paper [16]. In his work, the author [17], suggests a nonlinear model for the best route selection.

The model for transit task with a fixed set of transit routes is described in [10] and a label-setting algorithm was developed, which solves the latter issue in polynominal time. 
A model, in which containers are carried by freight routes of port rotations with given service frequencies, was developed by a group of authors [18]. For the purpose of minimising both the sailing time and the container dwell time at the port of origin and any intermediate transhipment ports, an origin-destination matrix of full containers is assigned to these strings. This entailed introducing two considerable model extensions. The first model extension involves the relocation of empty containers, aimed at balancing a net outflow of full containers from any port by a net inflow of empty containers, as well as the opposite. The second model extension entwines the inclusion of an upper limit to the maximum number of container moves per unit time at any port.

A group of authors in their research [19] expanded the frequency based approach presented by other researchers [18] to an intermodal network, adding services capacity constraints, loading/unloading and duty check times, while empty containers relocation is not dealt with. The above paper examines the container goal of optimisation on an intermodal network and propounds a linear programming algorithm. The efficiency and the effectiveness of the suggested approach, even in largesize instances, were proved by the computational results.

Application of a bi-objective optimisation is more justifiable than utilisation of a single-objective optimisation. This is supported by the fact that in real-life situations decision-makers often face situations in which they must handle conflicting objectives. In addition, more precise information on the observed objects is gained by inclusion of more objectives into the model.

The intermodal transport network design, which takes into account the total carbon dioxide emissions, is the central focus of research conducted by authors in [20]. The paper propounds a bi-objective locationtransportation model, which addresses the issue of assignment of flows on the intermodal network with a view to minimizing the total transportation costs and the carbon dioxide emissions.

A study aimed at minimizing both the transportation costs and $\mathrm{CO}_{2}$ emissions occurring in the course of transportation was presented by another group of authors in [21]. This model deals with a transportation scheduling problem, in which loads are carried from an overseas production base to several domestic demand centres.

The group of authors in paper [3] carried out a similar study, which involved testing the bi-objective optimisation, minimising cost and transit time, based on the import and export container flow to and from inland China. The analysis and final results provide managerial insights into the consequences of trade-offs between cost and transit time, and the effect of different carbon footprint needs on transport planning.

The relationship between the freight transport costs and the carbon dioxide emissions in given intermodal and truck-only freight networks was addressed by another group of authors in [22, 25, 26].

The developed tool [22] was implemented in a simplified freight transport network connecting two big European ports: the Port of Rotterdam and the Port of Gdansk. The initial result, based on the minimisation of transport costs, while the other solutions balanced with
$\mathrm{CO}_{2}$ emissions demonstrate that the mode share is altered in an intermodal transport system, based on a hub-andspoke network.

\section{Problem description}

This paper examines an intermodal transportation network, which is based on the import-way and composed of two legs. The first leg represents combination of deep see and short see shipping from the origin port to discharging ports. The second leg of the network represents the inland ingredient of the distribution, in which containers are transported from ports of unloading to the final destination, via truck, rail and barge.

Hence, through appropriate connection of nodes (loading port, unloading port and place of delivery) and links (deep-short sea and inland) the intermodal network was created. The detailed network is illustrated in Fig. 1. Such elements of the network are described below.

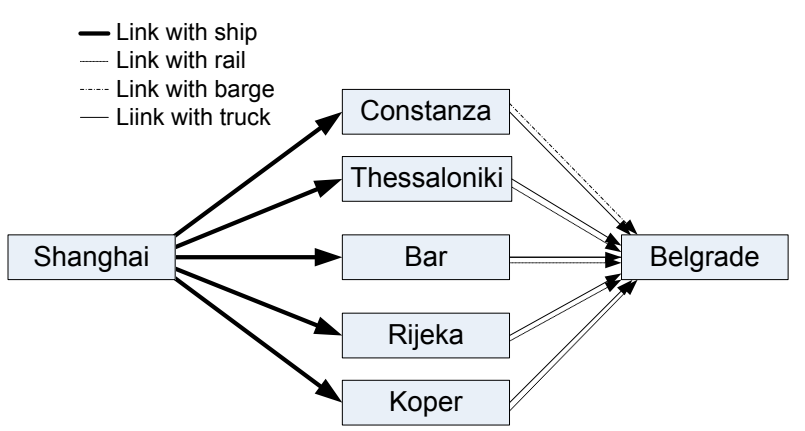

Figure 1 Intermodal container transport network

\subsection{Nodes}

Each node type has its own characteristics:

The port of origin-China, with its major port, the port of Shanghai, is one of the most important foreign trade partners in container imports from the Far East to Serbia. Shanghai is the world's busiest trading port which handles an astonishing 32 million containers per year, carrying 736 million tonnes of goods to the remotest places around the world.

Ports of discharge are linked with the port of origin, but only by incoming paths. From the port of origin, it is possible to catch up an unloading port, but the opposite is not allowed since here only incoming flows are being considered. The main gateways for container import to Serbia are Constanta, Thessaloniki, Bar, Rijeka and Koper port.

The destination - Serbia is a hinterland country, the capital city of which is Belgrade. This region represents the largest percentage of Serbian imports in general. It is connected directly to the unloading ports, representing the shortest direction for reaching it from that port of discharge, via truck, rail and barge.

\subsection{Links}

There are two types of links, maritime and inland, each one with its own characteristics, as described below:

Deep-short sea connections are those between the port of origin and unloading ports. On the maritime leg, 
six different container shipping lines (top six) were analysed with their different types of services on the westbound route networks from Shanghai to the gateway ports in the Mediterranean. Presently, there are 5,954 ships active on liner trades, for $18,022,997$ TEU and 228,921,278 TDW, including 4,967 fully cellular ships for 17,549,308 TEU. Fig. 2 shows the 10 largest container operators by displaying a special review of the number of ships and the total capacity expressed in TEU.

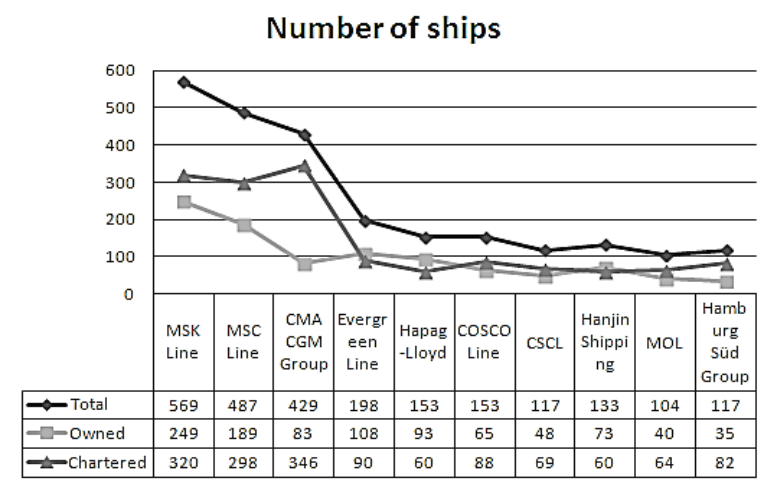

Number of TEU $\cdot 10^{6}$

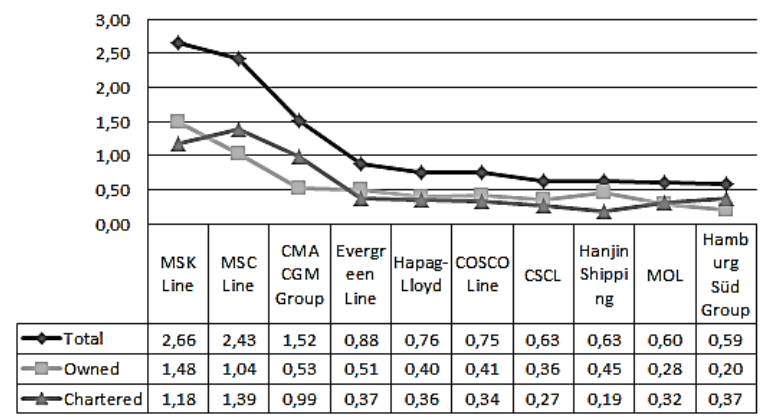

Figure 210 largest container operators (source: Alphaliner)

Briefly looking, inland connections are those between unloading ports and Belgrade - the final place of delivery. Barge, truck, and rail are three possible inland transportation modes. Before last mile delivery by truck, line-haul may be done also by barge or train, if there are available barge or rail linkages. In the absence of such facilities, containers could also be transported all the way from gateway ports to end-customers by truck. It is not possible to conduct all types of transport from each of the ports. Their interconnection is presented in Tab. 1.

Table 1 Modes of transport from discharge ports to final destination Ports / Modes of transport $\quad$ Truck Rail Barge

\begin{tabular}{|c|c|c|c|}
\hline Koper & $*$ & $*$ & \\
\hline Rijeka & $*$ & $*$ & \\
\hline Bar & $*$ & $*$ & \\
\hline Thessaloniki & $*$ & $*$ & \\
\hline Constanta & $*$ & & $*$ \\
\hline Connection with Belgrade & & & \\
\hline
\end{tabular}

\section{Model formulation}

To minimising transport costs and transit time, we applied a mathematical model based on bi-objective optimisation. A single-objective optimisation is less reasonable and realistic than a bi-objective optimisation. In addition, to get more reliable information about the monitored objects, it is necessary to include more objectives into the model. The two most common considerations in transport planning problems are transit time and cost.

Transit time of container flow, from the moment of the ship departure from the port of loading to the moment of arrival of container to the place of delivery in Belgrade, was analysed, considering six different operators, five discharge ports, along with three different types of services on the see legs. The total time includes containers waiting time at the port of discharge, depending on the different modes of transport from port of discharge to Belgrade.

The transport cost was considered for each of the most commonly used types of containers in the container transport, and it is based on the term - Free On Board (FOB). The total costs, in addition to the cost of transport from Shanghai to Belgrade, include local charges in the port of discharge, customs clearance and handling costs. Different modes of transport were used in inland transport, and because of more appropriate comparisons of the costs of rail and barge with truck, they included also handling costs at the terminal in Belgrade and final delivery to users by truck (local delivery).

Finally, this model provides a rank list and possibility to sort out and make a list of the best possible solutions with respect to minimisation of transit time and transportation costs.

\subsection{Definitions and notations}

Upcoming section brings the model formulation and corresponding explanations are given as follows:

Sets:

$N$ - set of nodes, let $N=S \cup E \cup B$, while $S$ stands for origin port, $E$ stands for gateway ports and $B$ stands for place of delivery

$A$ - set of arcs connecting an origin to a gateway (first-leg arcs)

$C$ - set of arcs connecting gateways to place of delivery (second-leg arcs)

Decision variables:

$t_{i j}$ - binary cost variable representing containers flow on first-leg arc, operator $\mathrm{i}$ to gateway $\mathrm{j}, t_{i j} \in\{0,1\}$

$l_{j k}$ - binary cost variable representing containers flow on second-leg arc, gateway $\mathrm{j}$, mode of transport $\mathrm{k}, l_{j k} \in$ $\{0,1\}$

$t t_{i j}$ - binary time variable representing containers flow on first-leg arc, operator $\mathrm{i}$ to gateway $\mathrm{j}, t t_{i j} \in\{0,1\}$

$t l_{k j}$ - binary time variable representing containers flow on second-leg arc, gateway $j$, mode of transport $k, t l_{j k} \in$ $\{0,1\}$

Parameters:

$i$ - number of operators, $i \in\{1, \ldots, 6\}$

$j$ - number of ports, $j \in\{1, \ldots, 5\}$

$t$ - type of container, $t \in\{1, \ldots, 3\}$

$\mathrm{s}$ - type of service, $s \in\{1, \ldots, 3\}$

$k$ - mode of transport, $k \in\{1, \ldots, 3\}$

$T S E_{i j s}$ - transit time on first-leg arcs (expressed in days)

$T E B_{j k}$ - transit time on second-leg arcs (expressed in days)

$\mathrm{CSE}_{\mathrm{ijt}}$ - transportation cost on first-leg arcs (expressed in USD)

$E X$ - exchange rate (EUR / USD) 
$C P C_{i j t}$ - port cost (expressed in EUR)

$C E B_{j k t}$ - transportation cost on second-leg arcs (expressed in EUR)

Objective functions:

Minimize Cost $=$

$\sum_{(i, j) \in A}\left(C S E_{i j} \frac{1}{E X}+C P C_{i j}\right) * t_{i j}+\sum_{(j, k) \in C} C E B_{j k} * l_{k j}(1)$

Minimize Time $=$

$\sum_{(i, j) \in A} T S E_{i j s} * t t_{i j s}+\sum_{(j, k) \in C} T E B_{j k} * t l_{j k}$

Constraints:

$\sum_{(i, j) \in A} t_{i j}=1$

$\sum_{(j, k) \in C} l_{j k}=1$

$\sum_{(i, j) \in A} t_{i j}=\sum_{(j, k) \in C} l_{j k}, \forall j$

$\sum_{(i, j) \in A} \sum_{s} t t_{i j s}=1$

$\sum_{(j, k) \in C} t l_{j k}=1$

$\sum_{i, s} t t_{i j s}=\sum_{k} t l_{j k}, \forall j$

Corresponding Explanations:

The objective function (1) minimises the total costs of container import flow through the transport network. They include transport costs on the first leg-arc (ocean costs), port costs and transport costs on the second leg-arc (costs of using inland vehicles - truck, rail and barge). The objective function (2) minimises the total transit time of container import from Shanghai to Belgrade. Constraints (3) and (4) define a single best solution for the costs from a group of ordered pairs on the maritime and inland part. Constraint (5) selects the same port for the first and second leg-arc and defines one route from origin to place of delivery regarding transportation cost. Constraint (6) defines a single best solution for transit time on the ocean and depends on a different type of service. Constraint (7) gives a single best solution for transit time on the second leg-arc. The constraint (8) selects the same port for the first and second leg-arc and represents one route from the origin to the place of delivery with regard to transit time.

In view of the wide range of interaction with the user, taking into account the troubleshooting with Pareto frontier and genetic algorithms and in accordance with the nature of the problem, this paper offers a method with subjective determination of weights, where each user has the ability to define the importance of each of the considered criteria.

The proposed mathematical model offers a broad range of solutions $\left(Z_{f i n}\right)$ and provides the possibility of their ranking. Through a selection of different cost $(\alpha)$ and transit time $(\beta)$ coefficients, calculated by means of weighting, certain groups of optimal solutions are obtained, presenting the adequate minimisation of the used parameters.
Cost rank list: $Z_{1}=\min \left(\begin{array}{c}c_{1} \\ c_{2} \\ \vdots \\ c_{n-1} \\ c_{n}\end{array}\right)$

$\mathrm{CO}_{2}$ emission rank list: $Z_{2}=\min \left(\begin{array}{c}t_{1} \\ t_{2} \\ \vdots \\ t_{n-1} \\ t_{n}\end{array}\right)$

The final bi-objective rank list:

$$
Z_{\text {fin }}=\frac{1}{\alpha+\beta} \min \left(\begin{array}{c}
\frac{\alpha c_{1}}{z_{1}}+\frac{\beta t_{1}}{z_{2}} \\
\frac{\alpha c_{2}}{z_{1}}+\frac{\beta t_{2}}{z_{2}} \\
\vdots \\
\frac{\alpha c_{n-1}}{z_{1}}+\frac{\beta t_{n-1}}{z_{2}} \\
\frac{\alpha c_{n}}{z_{1}}+\frac{\beta t_{n}}{z_{2}}
\end{array}\right)
$$

\section{$5 \quad$ Results and discussions}

In this section, the results obtained by the developed bi-objective optimisation model (BOOM), minimising the transit time and transportation costs of container import from Shanghai to Belgrade, are analysed. BOOM was programmed in MATLAB and simulations were carried out on a Dual Core E5200 $2.5 \mathrm{GHz}$ computer. The original input data for the period July-August 2013 were used.

We observed five different scenarios and each of them gave us optimal solutions for various specified criteria. The results of our investigations are shown below.

Table 2 Optimal transit time

\begin{tabular}{ll}
\hline \multicolumn{1}{c}{ Port of loading } & \multicolumn{1}{c}{ Shanghai } \\
\hline Operator & COSCO \\
Number of trans-shipments & 1 \\
Service & CESS / AFS \\
Route & $\begin{array}{l}\text { Shanghai - Ningbo - Shekou - } \\
\text { Singapore - Port Kelang - } \\
\end{array}$ \\
& Piraeus / Piraeus - Thessaloniki \\
& Thessaloniki \\
Port of discharge & Truck \\
Mode of transport & Belgrade \\
Place of delivery & 28 days \\
Optimal transit time & 2189 EUR \\
Rate 20 DV & 3216 EUR \\
Rate 40 DV & 3253 EUR \\
Rate 40 HQ & $17498 \mathrm{~km}$ \\
Distance &
\end{tabular}

Scenario 1: We concern one-objective optimisation ("Min time"), the results of which are presented in Tab. 2. In this scenario, the optimal transit time between Shanghai and Belgrade is 28 days using see and land legs together. The operator COSCO using China/Europe Shuttle Service - CESS, with one trans-shipment in Piraeus, illustrated in Fig. 3, and Adriatic Feeder Service AFS service illustrated in Fig. 4, on the first-leg arc reaches the unloading port, the port of Thessaloniki, and continues on the second-leg arc using the truck service for transport to the final destination Belgrade. With respect to 
the optimal time, the BOOM also determines the transportation costs for each type of container, as well as the total distance.

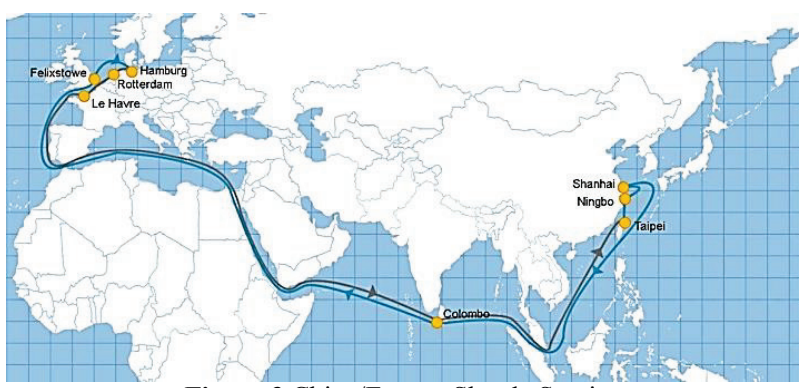

Figure 3 China/Europe Shuttle Service

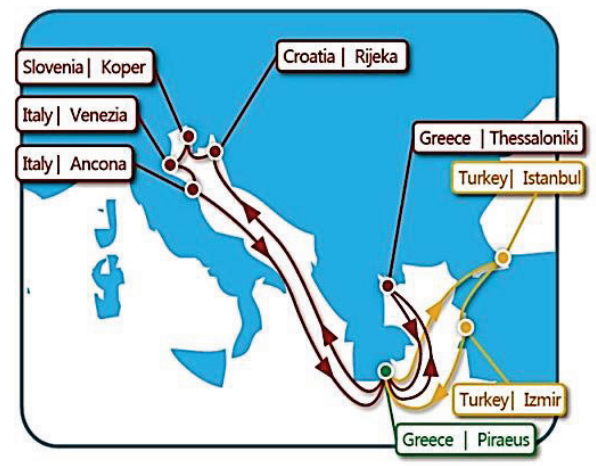

Figure 4 Adriatic Feeder Service

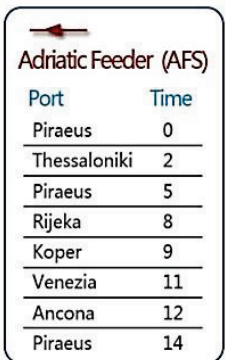

The total transit time between Shanghai and Belgrade includes: the transit time between Shanghai and Piraeus 23 days; the waiting time (for feeder to Thessaloniki) in Piraeus - 2 days; the transit time from Piraeus to Thessaloniki - 1 day; the waiting time at the port of Thessaloniki - 1 day; the transit time from Thessaloniki to Belgrade by truck - 1 day.

Table 3 Optimal transportation cost

\begin{tabular}{ll}
\hline Port of loading & Shanghai \\
\hline Operator & MSC \\
Number of trans-shipments & 1 \\
Service & $\begin{array}{l}\text { DRAGON / WEST } \\
\text { MEDITERRANEAN }\end{array}$ \\
Route & $\begin{array}{l}\text { Shanghai - Yantian - Hong } \\
\text { Kong - Chiwan - Singapore - } \\
\text { GioiaTauro / GioiaTauro - } \\
\end{array}$ \\
& Rijeka \\
Port of discharge & Rijeka \\
Mode of transport & Rail \\
Place of delivery & Belgrade \\
Optimal rate 20 DV & EUR 1,639 \\
Transit time & 35 days \\
Distance & $17209 \mathrm{~km}$ \\
\hline
\end{tabular}

Scenario 2: In this scenario, one-objective optimisation ("Min cost") was analysed, where the optimal transportation costs between Shanghai and Belgrade per each container (20 DV, 40 DV, $40 \mathrm{HQ}$ ) are respectively EUR 1,594,EUR 2,470,EUR 2,483, using the see and land legs together. These data are valid for the period August 2010. Since container transport on the Danube River (barge transport) from Belgrade to Constanta is not currently active, these data can be regarded as hypothetical. The first valid data with respect to the minimum price for the transport between Shanghai and the Belgrade base on FOB basis per TEU is EUR 1,639, while the results are presented in Tab. 3 .

Scenario 3: In this scenario we considered one objective optimization ("Rank list by time") and the results are illustrated in Fig. 5. The objective criteria represent the full range of solutions assigning a price for each type of container to the each transit time on the range between 28 and 49 days. When the time is equal in some cases, BOOM gives us also the possibility to make a rank list by the second criteria (choosing different type of container). In terms of transit time between Shanghai and Belgrade, using different service of each of operators, 35 days is the most usual frequency.

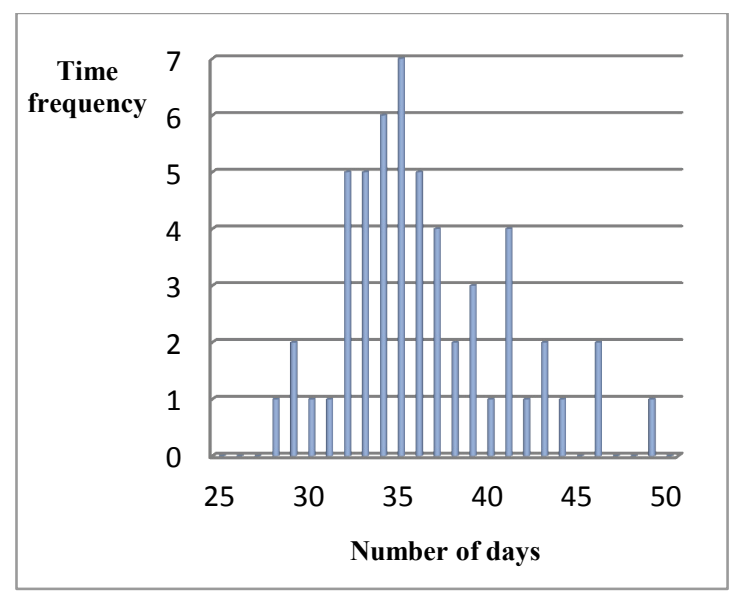

Figure 5 Rank lists by time

Scenario 4: In this scenario we discussed one objective optimization ("Rank list by cost"). The objective criteria represent the full range of solutions for each type of container and showed as information about distance and transit time. Observing the results we spotted that the cost for $20 \mathrm{DV}$ ranged between $1594 \div 3219$ EUR, $40 \mathrm{DV}$ between $2470 \div 4230$ EUR and 40 HQ between $2483 \div$ 4297 EUR. The results which represent total cost per TEU are sorted by ascending order and provide us credible information about the transit time and their exact place in the ranking list on the transportation route between Shanghai and Belgrade. The first 50 solutions are illustrated in Fig. 6.

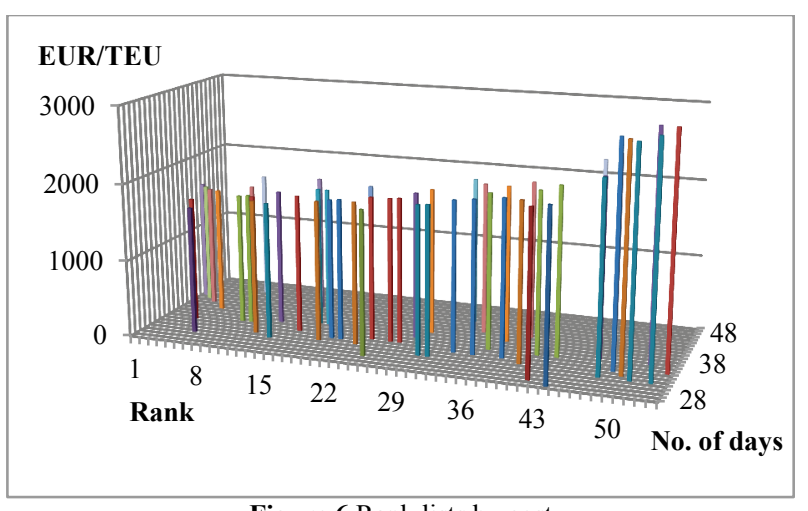

Figure 6 Rank lists by cost

Scenario 5: It represents the most optimal route base on bi-objective optimization regarding cost and time together. Each of minimal objectives, cost and time have 
the same value (100). The rest of the costs and times are scaled. As the sum of these values we got the most optimal route where the percentage of significance of both variables, cost and time are equal. The optimal solution for transport of 1 TEU from Shanghai to Belgrade is operator COSCO regarding the cost of 1657 EUR and the transit time of 31 day. The port of discharge is Rijeka and the mode of transport is rail. The simulation results are presented in Fig. 7.

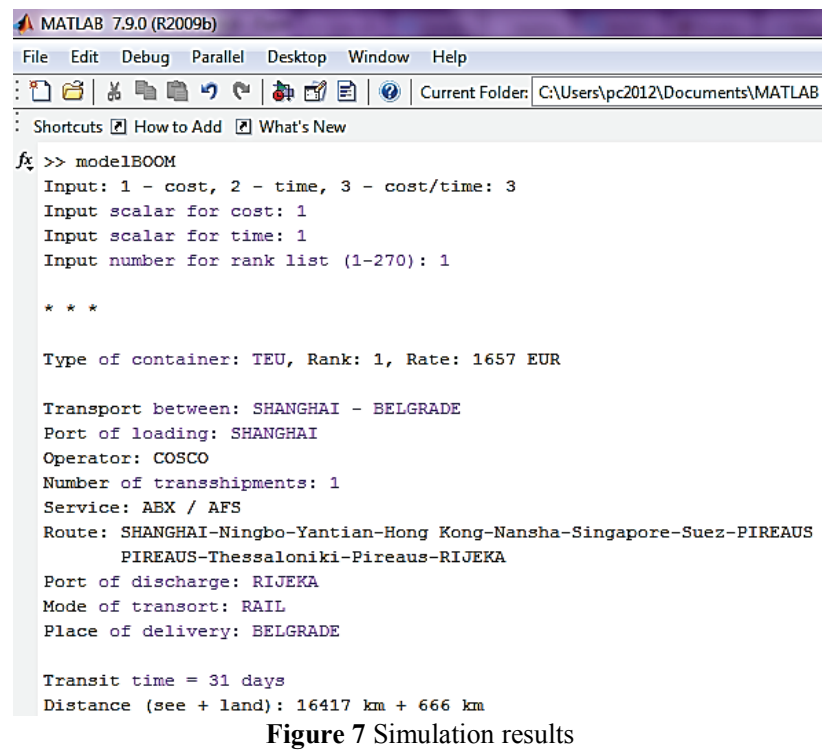

The group of authors in their paper [23] presented minimisation of transportation cost and transit time. They have formed a model to examine the competitiveness of 36 alternative routings for freight moving from China to and beyond the Indian Ocean. The proposed model is capable of handling multiple and conflicting objective functions, such as minimising transportation cost, transit time and transit time variability. Transportation time and cost obtained from comprehensive industry sources are then fed into the intermodal transport network connecting two important Chinese origins and four Indian destinations, from which the most attractive routes are identified.

The international intermodal routing problem is examined in the paper [24]. In this paper author focused on one of the intermodal operational issues: how to select best routes for shipments through the international intermodal network. International intermodal routing is complicated by three important characteristics: (1) multiple objectives; (2) scheduled transportation modes and demanded delivery times; and (3) transportation economies of scale.

\section{Conclusion and future research}

This paper analyses the supply-chain network focusing on container import from the Far East (the Port of Shanghai) to Serbia (the city of Belgrade) through selected Mediterranean ports (Koper, Rijeka, Bar, Thessaloniki and Constanta), considering the six world's largest container transport carriers (MSK, MSC, CMA CGM, EMC, COCSO and Hapag-Lloyd) without prejudice of their different types of services. Serbia is a hinterland country and container import from the Far East to Serbia entails the combination of the deep and short see shipping with different inland transportation modes such as truck, rail and barge. Certain groups of customers require the lowest freight rates, while others give priority to a faster delivery. The main objective of this research is to ensure an optimal route with the shortest transit time and the lowest transportation cost of container import from Shanghai to Belgrade.

The paper proposes a mathematical model, which provides the possibility for obtaining reliable data with the minimal transit time and transport cost per each container type. The advantage of this mathematical model is that, in addition to the optimal price and transit time, it provides also the possibility for the observation the group of all possible solutions, which are ranked in ascending order.

Based on a bi-objective optimisation, considering transportation cost and transit time together, the optimal route for container transport from Shanghai to Belgrade, choosing the operator COSCO for the ocean freight and rail transport from Rijeka to Belgrade, was determined.

The contribution of this paper demonstrates that the experimental results have more than a scientific value, since they can be applied in practice. Furthermore, the authors tested different scenarios, with the real input data and one hypothetical view. The application of the model is simple. In order to improve the business models of companies this model is highly recommended comprehensively emphasizing the savings in time and costs reduction.

Further research is needed, because this research has recited only part of the problem. It can be extended in the future and can be imported with a lot of new nodes with the main objective to minimize time and cost of container flow.

\section{Acknowledgements}

The study was carried out within the Project TP 36027, "Software development and national database for strategic management of the development of means of transport and infrastructure in road, rail, air and water transport by European transport network models", financed by the Ministry of Education Science and Technological Development, Republic of Serbia. This paper was presented in the short version at ICIL 2014 International Conference on Industrial Logistics, Bol, Brac, Croatia, June 2014.

\section{$7 \quad$ References}

[1] Review of Maritime Transport: UNCTAD/RMT/2015, United National Publication Sales no. E.15.II.D.6, ISBN 978-92-1-112892-5, e-ISBN 978-92-1-057410-5, ISSN 0566-7682.http://unctad.org/en/publicationslibrary/rmt2013 en.pdf (06.12.2013).

[2] Teodor, G. C.; Kap, H. K. Intermodal Transportation. // Handbooks in Operations Research and Management Science, 14, (2007), pp. 467-537. DOI: 10.1016/S09270507(06)14008-6

[3] Lam, J. S. L.; Gu, Y. Port Hinterland Intermodal Container Flow Optimization with Green Concerns: A Literature Review and Research Agenda. // International Journal of 
Shipping and Transport Logistics (IJSTL). 5, 3(2013), pp. 257-281. DOI: 10.1504/IJSTL.2013.054190

[4] Infante, D.; Paletta, D.; Vocaturo, F. A Ship-truck Intermodal Transport Problem. // Maritime Economics \& Logistics. 11, 3(2009), pp. 247-259. DOI: 10.1057/mel.2009.6

[5] Kim, H. J.; Chang, Y. T.; Lee, P. T. W.; Sin, S. H.; Kim, M. J. Optimizing the Transportation of International Container Cargoes in Korea. // Maritime Policy \& Management. 35, 1 (2008), pp. 103-122. DOI: 10.1080/03088830701849084

[6] Payman, J.; Robert, C. L. Long- and Short-Run supplychain optimization models for the allocation and congestion management of containerized imports from Asia to the United States. // Transportation Research Part E. 47, (2011), pp. 593-608. DOI: 10.1016/j.tre.2011.02.006

[7] Newman A. M.; Yano C. A. Scheduling Direct and Indirect Trains and Containers in an Intermodal Setting. // Transportation Science. 34, 3(2000), pp. 256-270. DOl: 10.1287/trsc.34.3.256.12297

[8] Francesetti, D. C. Italian versus Northern Range port competitiveness: a transportation cost analysis in Chinese trade. // European Transport - Trasporti Europei. 30, (2005), pp. 37-53

[9] Han, M. M.; Guolong, L.; Bin, Y. A Linear Programming Model for Short Sea Shipping and Multimodal Inland Transportation in Myanmar. // Report and Opinion. 3, 1 (2011), pp. 37-43

[10] Spiess, H.; Florian, M. Optimal strategies: A new assignment model for transit networks. // Transportation Research Part B: Methodological. 23, 2(1989), pp. 83-102. DOI: 10.1016/0191-2615(89)90034-9

[11] Wong, S. C.; Tong, C. O. A stochastic transit assignment model using a dynamic schedule-based network. // Transportation Research. 33B (1999), pp. 107-121.

[12] Shortest Path Algorithms. // Handbook of Optimization in Telecommunications / Festa, P. Naples: Springer US, 2006.pp. 185-210.

[13] Nuzzolo, A.; Russo, F.; Crisalli, U. A Doubly Dynamic Schedule-based Assignment Model for Transit Networks. // Transportation Science. 35, (2001). pp. 268-285. DOI: 10.1287/trsc.35.3.268.10149

[14] Harker, P. T; Friesz, T. L. Prediction of intercity freight flows, i: Theory. // Transportation Research Part B. 20, 2(1986), pp. 139-153. DOI: 10.1016/0191-2615(86)90004-4

[15] Harker, P. T.; Friesz, T. L. Prediction of intercity freight flows, ii: Mathematical formulation. // Transportation Research Part B. 20, 2(1986), pp. 155-174. DOl: 10.1016/0191-2615(86)90005-6

[16] Crainic, T. G.; Florian, M.; Guelat, J.; Spiess. H. Strategic planning of freight transportation: Stan, an interactivegraphical system. // Transportation Research Record. 1283, (1990), pp. 97-124.

[17] Chang, T. S. Best routes selection in international intermodal networks. // Computers \& Operations Research, 35, 9(2008), pp. 2811-2891. DOI: 10.1016/j.cor.2006.12.025

[18] Bell, M. G. H.; Liu, X.; Angeloudis, P.; Fonzone, A.; Hosseinloo, S. H. A frequency- based maritime container assignment model. // Transportation Research Part B. 45, (2011), pp. 1152-1161. DOI: 10.1016/j.trb.2011.04.002

[19] Maurizio, A.; Simona, M.; Andrea, R. Formulating a mathematical model for container assignment optimization on an intermodal network. // Procedia - Social and Behavioral Sciences, 111, (2014), pp. 1063-1072. DOI: 10.1016/j.sbspro.2014.01.141

[20] Mostert, M.; Limbourg, S. A bi-objective model for intermodal transport. // Proceedings of the 5th International Conference on Information Systems, Logistics and Supply Chain CONNECTING WORLDS ILS / Breda, 2014, pp. 107-114.

[21] Ohnishi, M. An International Transport Route Optimization Problem with Timetables of Ships and Airplanes. //
Proceedings of the $19^{\text {th }}$ RAMP Symposium (2007), pp. 151161.

[22] Kim, N. S.; Janic, M.; Bert, V. W. Trade-Off Between Carbon Dioxide Emissions and Logistics Costs Based on Multi-objective Optimization. // Transportation Research Record: Journal of the Transportation Research Board. 2139, (2009), pp. 107-116.

[23] Yang, X.; Low, J. M. W.; Tang, L. C. Analysis of Intermodal Freight from China to Indian Ocean: A Goal Programming Approach. // Journal of Transport Geography. $\quad 19,4(2009), \quad$ pp. 515-527. DOl: 10.1016/j.jtrangeo.2010.05.007

[24] Tsung-Sheng, C. Best routes selection in international intermodal networks. // Computers \& Operations Research, 35, 9(2008), pp. 2877-2891. DOI: 10.1016/j.cor.2006.12.025

[25] Lerher, T.; Sraml, M.; Borovinsek, M.; Potrc, I. Multiobjective optimization of automated storage and retrieval systems: Annals of the Faculty of Engineering Hunedoara, 11, 1(2013), pp. 187-194

[26] Lerher, T.; Borovinsek, M.; Sraml, M. A multi objective model for optimization of automated warehouses. // Logistics perspectives, approaches and challenges. (2013), pp. $87-110$.

\section{Authors' addresses}

Radoslav Rajkovic, Research Assistant

University of Belgrade,

Faculty of Mechanical Engineering,

Innovation center,

Kraljice Marije 16, 11000 Belgrade, Serbia

E-mail: radoslav.rajkovic@gmail.com

E-mail: rrajkovic@mas.bg.ac.rs

Nenad Zrnic, PhD, Full Professor

University of Belgrade,

Faculty of Mechanical Engineering,

Kraljice Marije 16, 11000 Belgrade, Serbia

E-mail: nzrnic@mas.bg.ac.rs

Djordje Stakic, PhD student

University of Belgrade,

Faculty of Mathematics,

Studentski trg 16, 11000 Belgrade, Serbia

E-mail: djordjes@gmail.com 